\title{
ANALYSIS OF THE EFFECT OF GLOBALIZATION USERS' COLOR PREFERENCES OVER LIVING SPACE FURNITURE
}

\author{
Aylin ARAS \\ Karadeniz Technical University, TURKEY \\ https://orcid.org/0000-0003-3315-3655 \\ aylin@ktu.edu.tr
}

\begin{abstract}
The concept of globalization has taken many topics under its influence in recent years. Residential designs in which users reflect their identities are also influenced and formed by globalization. The concept of color which causes different perceptions among humans also emerges as one of the important parameters of space design. It is also observed as a result of literature reviews that colors of furniture as one of the most important building blocks of space affect perception of space. Globalization that is effective in exhibiting similar or different behaviors by societies is considered to be effective in selection of furniture colors that affect individuals' lifestyles or get affected from their lifestyles and that also affect perception of space. Departing from this idea, it has been discussed whether globalization affects color preferences for furniture in living spaces of buildings that contain all kinds of data related to people's lives and perceptions. Within the scope of the research, color preferences furniture used in living spaces were determined between users heavily affected from globalization and users less affected from globalization. In this context; on-site evaluation studies and surveys were applied in houses of two different groups determined as the sample field, and colors chosen by individuals in furniture of living spaces of sample groups were examined. As a result of the study, it was determined that users in two different sample groups used different colors in furniture of their building living spaces.
\end{abstract}

Keywords: Globalization, furniture, color, building living spaces, user preferences

\section{KÜRESELLEŞMENIN KULLANICILARIN RENK TERCIHLERINE ETKİSININ YAŞAMA MEKÂNI MOBİLYALARI ÜZERINDEN İNCELENMESİ}

\begin{abstract}
ÖZ
Küreselleşme kavramı son yıllarda ekonomiden, tasarıma kadar pek çok konuyu etkisi altına almaktadır. Kullanıcıların kimliklerini yansıttıkları konut tasarımları da küreselleşmeden etkilenerek şekillenmektedir. İnsanlarda farklı algılamalara sebep olan renk kavramı da mekân tasarımının önemli parametrelerinden biri olarak karşımıza çıkmaktadır. Mekânın en önemli yapı taşlarından biri olan mobilyalarda kullanılan renklerin de mekân algısını etkilediği yapılan literatür çalışmalarında görülmektedir. Toplumların benzer ya da farklı davranışlar sergilemesinde etkili olan küreselleşmenin, insanın yaşam tarzını etkileyen veya yaşam tarzından etkilenen en önemli öğelerden olan ve mekân algısını etkileyen mobilyaların renk seçiminde de etkili olduğu düşünülmektedir. $\mathrm{Bu}$ düşünceden hareketle küreselleşmenin, insanın yaşama ve algılarına dair her türlü veriyi içinde barındırdığı konut yaşama mekânlarındaki mobilyaların renk tercihlerini etkileyip etkilemediği incelenmiştir. Çalışma kapsamında, küreselleşmeden yoğun olarak etkilenen kullanıcılarla, daha az etkilenen kullanıcıların konut yaşama mekânlarında kullandıkları mobilyalardaki renk tercihleri belirlenmiştir. Bu kapsamda; örneklem alanı olarak belirlenen iki farklı gruba anket ve konutlarında yerinde tespit çalışmaları yapılmış ve örneklem gruplarının yaşama mekânı mobilyalarında seçmiş oldukları renkler incelenmiştir. Çalışma sonucunda iki farklı örneklem grubundaki kullanıcıların konut yaşama mekânı mobilyalarında farklı renkler kullandıkları belirlenmiştir.
\end{abstract}

Anahtar Kelimeler: küreselleşme, mobilya, renk, konut yaşama mekânları, kullanıcı tercihleri 


\section{INTRODUCTION}

Architectural space is the space that user perceives with his/her experiences (Kasap, 2009). In other words, how users perceive a space is associated with knowledge that they have obtained in life. Nowadays, while people gain knowledge on life, they make use of both places they visit and communication tools they use. An individual's travel habits, social and digital communication tools he/she uses affect his/her knowledge, lifestyle and tastes. Today, being effective in every aspect of life, globalization also affects mobility of people and their knowledge. Thanks to globalization, communication has accelerated, borders have begun to disappear, this situation has been reflected on both individuals' lives and living spaces. Thanks to globalization, changes occurring with pace in the society have also changed buildings, and tastes in housing and furniture. Lifestyles evolving with production-consumption habits, product and service flow, technological developments and current trends in the world with the effect of globalization also allow users to think about furniture in a broader perspective. Color is known as one of the important criteria in choosing furniture such as material and style. Therefore, it is considered that there are differences among furniture color preferences between users affected more from globalization and those affected less.

The concept of color emerges as one of the major elements in perceiving architectural space. Colors in designed structured environment affect identity of the space and user's perception of a space (Manav, 2011). In addition to many factors allowing perception of space such as color, light, dimensions etc., appearances of furniture also affect perception of space. Apart from factors such as ergonomics, material, texture in furniture preferences, color is also one of important criteria and affects perception of space (Altan, 1993). Therefore, it is necessary to consider the effect of colors in space design and color preferences of furniture. That is because colors used for spaces and furniture also give opinions about users' personality to others (Manav, 2011).

Color is a concept that is effective in every aspect of life and represents an individual's tastes. Besides, color adds aesthetic values to spaces, but also bears symbolical meanings that designers use to give various messages to others (Açıc1, 2015). Considering factors related to color in perception of space; all factors including physiological, physical and psychological ones should be taken into consideration (Sheppard, 1968). Colors are also used as a tool of expression and narration with codes related to colors established in human mind in daily life (Manav, 2015). For example, while white color symbolizes purity and is used to attract elegant customers, brown represents richness and natural such as soil (Açıc1, 2015). The concept of color is also very effective in communicating physically and psychologically among individuals. Thanks to coding established in human mind with colors, users get some perceptions about a space with attributes such as cold-warm-friendly-comfortable, and spaces can be used as tools of expressing emotions. In this way, space gains identity (Manav, 2015).

In color preferences, there are many factors ranging from psychological factors to conditioned reflexes, from user identity to fashion (Özdemir, 2005). It is known that fashion is affected from globalization and spread with communication tools. User identity is also formed with his/her sociocultural features. This can be associated with data related to globalization. In other words, it is considered that globalization is a factor in color preferences though indirectly, because experiences obtained with the help of different tools are also effective in perception of space.

Buildings emerging as spaces in which users reflect their personal properties and lifestyles also represent users' color preferences (Özdemir, 2005). That is because, while function is prominent in buildings other than houses, users' personal preferences, lifestyles and their cultural data come into prominence and these are reflected on space. Therefore, the issue of whether globalization is an effective factor in furniture color preferences has been discussed over buildings.

Furniture used in buildings vary as per the cultural group (Aras, 2015). Just like furniture used, it is considered that colors preferred in furniture may vary in different groups of the society. Features such as communication tools, social organizations and fast-moving consumer culture that can be used to determine effects of globalization influence users' perceptions and thus their perspective on colors. Users in similar socio-cultural structure show similar consumption habits (Hofstede, 1991; Chaney, 1999). Because of this, differences can be seen among color choices of users that have different consumption characteristics (Özdemir, 2005; Manav, 2015). 
With this study applied, a discussion has been made on household users' furniture color preferences that are differently affected from globalization and that show differences according to frequency of using communication tools. In this first section of the study, literature information about the effect of color and globalization on space was given. In the second section, on-site evaluation studies were conducted towards determination of furniture colors used in living spaces by means of surveys to reveal effect of globalization on users. Within the scope of this study, it is examined whether there are differences in color preferences for furniture between users who use communication tools or those do not, who engage in socio-cultural activities or those do not.

\section{STUDIES CONDUCTED}

\section{Selection of Sample}

Effects of globalization can be observed in the distinct groups of different regions in a city. The research was conducted in Trabzon since it is a city receiving continuous migration from surrounding provinces and contains social structures in distinct characteristics in different parts of the city. In the research conducted in two different regions of Trabzon province with different social-economic levels, the objective was to determine furniture color preferences among users affected from globalization in different forms.

Use of communication tools among users means that they are affected from social organizations, their travel habits affect users with environmental data, in other words, with globalization. Using communication tools, ability to travel and participating in social activities are generally associated with users' educational background. Users with good educational background and income level generally travel more, follow fashion more and use communication tools more, so they are affected by globalization faster and more. It is considered, based on the idea that individuals living in the same apartment block are affected from each other (Ayata and Ayata, 1996), that user from the same apartment block tend to exhibit similar behaviors in terms of globalization although their educational background and income levels are different. For this reason, these data were questions first in the sample.

According to data from Turkey Statistical Institute (TSI), since there are no data on income level based on neighborhood basis, by determining the educational level belonging to central district, survey application areas were determined as Beşirli Neighborhood No.1 with the highest rate of higher education graduation $(27.9 \%)$ and Cumhuriyet Neighborhood with the least rate of higher education graduation $(6.6 \%)$. Stemming from the educational level, the sample group was determined, then it was analyzed in terms of income level. Therefore, the objective was to determine "economic status and educational level" which was considered to affect globalization data among users in sample group who used communication tools (social media, magazines, newspapers, TV programs etc.).

According to TSI data, it was identified that number of people living is Beşirli Neighborhood No.1 was 8203, and number of those living Cumhuriyet Neighborhood was 4531. To represent the main mass determined within the scope of this study $(\mathrm{N}=8203$ and $\mathrm{N}=4531)$, sample size for Beşirli Neighborhood No.1 was found as 97, and 67 for Cumhuriyet Neighborhood together with $90 \%$ reliability level $(\mathrm{t}=1.64)$ and $10 \%$ margin of error $(\mathrm{d}=0.1)$ values.

For Beşirli Neighborhood No.1;

$$
n=\frac{8203 *(1,64)^{2} * 0,5 * 0,5}{\left[(0,1)^{2} * 8202\right]+\left[(1,64)^{2} * 0,5 * 0,5\right]}=66,70 \cong 67
$$

For Cumhuriyet Neighborhood;

$$
n=\frac{4531 *(1,64)^{2} * 0,5 * 0,5}{\left[(0,1)^{2} * 4530\right]+\left[(1,64)^{2} * 0,5 * 0,5\right]}=66,27 \cong 67
$$


In the light of the data obtained, it was determined that housing prices was at the highest level in Beşirli Neigborhood No.1, namely there were users belonging to the highest income level living in Yeşil Park Site, and these housing areas of the study were selected as above-mentioned Yeşil Park Site and Afet Evleri that had been built to meet housing needs emerging as a result of disasters (Aras, 2015).

The study was conducted in 134 dwelling houses 50\% of which were in Yeşil Park Site and 50\% of which were in Afet Evleri in the sample group statistically verified as belonging to two different social structure.

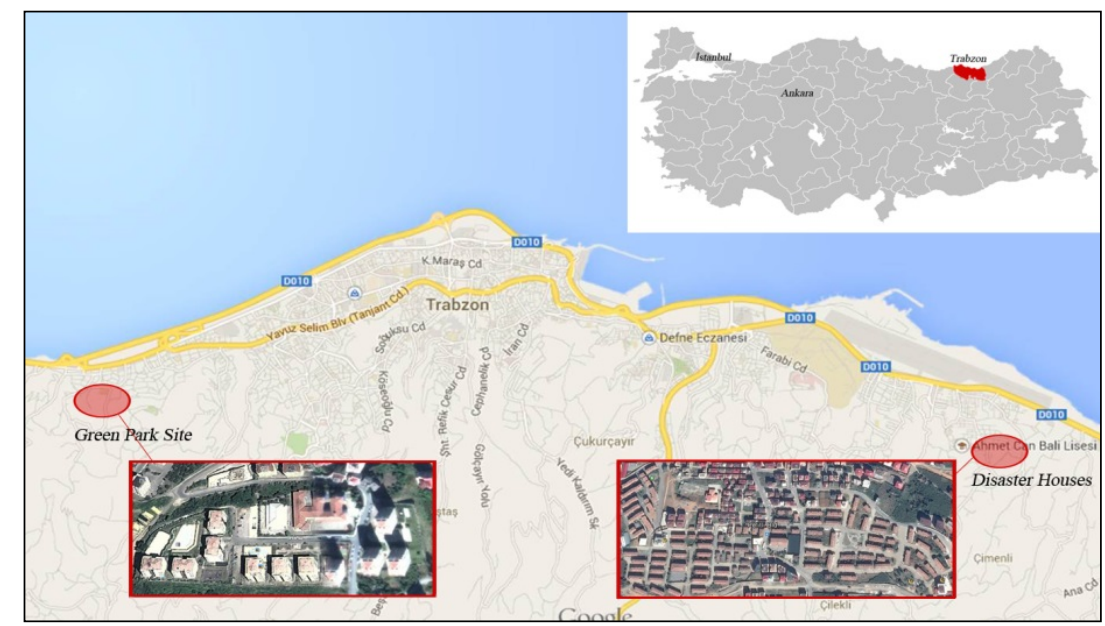

Figure 1. Place of working space in the map

\section{Survey Design}

The study was conducted in dwelling houses belonging to user who were determined to have in different social structure in Interaction of Culture Components and Cultural Groups in Spatial Organizations Choosing Furniture: House Living Rooms prepared by Aras (Arasi 2015). Difference among users' use of communication tools and traveling habits were identified with the survey study conducted. This application is thought to demonstrate that both groups are affected differently from globalization. In the survey, users were asked questions towards determining demographic structure and effect of globalization of users. Within the scope of survey, a total of 12 questions were asked including 3 questions towards determining users' income level, educational level and connection with city and 9 questions towards determining the effect of globalization on users.

In on-site detection study, an application was carried out to determine which colors users use in their furniture in living spaces based on their different social structure. To determine fabric colors of furniture in the form created, a scale was established with white color used in modern architecture in addition to red, blue, yellow, green, brown and black colors used in traditional Turkish housing couches as specified by Küçürerman (Küçükerman, 1991). Then data obtained in the determination study was transferred to SPSS (Statistical Packages for the Social Sciences) software in computer environment using appropriate coding, they were analysed with this program.

\section{FINDINGS}

In the study, selection of sample groups was conducted based on dwelling units determined as having different social structures using Aras's study named "Space Organization and Interaction of Culture Groups and Cultural Components in Furniture Selection: Building Living Spaces" (Aras, 2015).

Sample group determined within the scope of the study;

- Data related to social structure

- Data on globalization 
- Data was analysed in accordance with data on furniture color preferences, and obtained findings were analyzed.

\section{Findings Related to Social Structure}

In data obtained from social structure, data on income level, educational level and residing in Trabzon were assessed. Analysing sample groups in terms of their socio-economic level titles taken under assessment from the point of social structure, it was determined that users in Afet Evleri and Yeşil Park Site were in different social structure. That is because, when compared with users from Yeşil Park Site, users from Afet Evleri belongs to lower income group with lower educational level and people migrating to Trabzon (Table 1).

Table 1. Relationship among sample groups in terms of social structure (Aras, 2015)

\begin{tabular}{|c|c|c|c|c|c|}
\hline \multicolumn{2}{|c|}{ Social-economic level } & Sample group & $\%^{*}$ & $\begin{array}{l}\text { Adj. } \\
\text { Res. }\end{array}$ & Reason for difference; \\
\hline \multirow{10}{*}{ 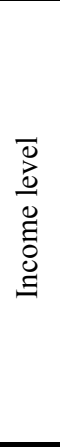 } & \multirow{2}{*}{ Less than TRY 1000} & Afet Evleri & 15,7 & 5,0 & \multirow{10}{*}{$\begin{array}{l}\text { Users from Afet Evleri belong to lower income } \\
\text { group, } \\
\text { Users from Green Park belong to the upper } \\
\text { income group. }\end{array}$} \\
\hline & & Yeşil Park Site & 0,0 & $-5,0$ & \\
\hline & Between TRY 1000- & Afet Evleri & 32,1 & 7,3 & \\
\hline & 2000 & Yeşil Park Site & 2,2 & $-7,3$ & \\
\hline & Between TRY 2001- & Afet Evleri & 2,2 & 0,0 & \\
\hline & 3000 & Yeşil Park Site & 2,2 & 0,0 & \\
\hline & \multirow{2}{*}{$\begin{array}{r}\text { Between TRY 3001- } \\
4000 \\
\end{array}$} & Afet Evleri & 0,0 & $-3,6$ & \\
\hline & & Yeşil Park Site & 9,0 & 3,6 & \\
\hline & \multirow{2}{*}{ More than TRY 4000} & Afet Evleri & 0,0 & $-8,8$ & \\
\hline & & Yeşil Park Site & 36,6 & 8,8 & \\
\hline \multirow{12}{*}{ 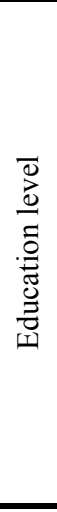 } & \multirow{2}{*}{ Illiterate } & Afet Evleri & 6,0 & 2,9 & \multirow{12}{*}{$\begin{array}{l}\text { That is because users from Yeşil Park Site have } \\
\text { - higher educational level than users from Afet } \\
\text { Evleri. }\end{array}$} \\
\hline & & Yeşil Park Site & 0,0 & $-2,9$ & \\
\hline & \multirow{2}{*}{$\begin{array}{r}\text { Literate/elementary } \\
\text { school }\end{array}$} & Afet Evleri & 27,6 & 7,1 & \\
\hline & & Yeşil Park Site & 0,0 & $-7,1$ & \\
\hline & \multirow{2}{*}{ Secondary School } & Afet Evleri & 8,2 & 1,3 & \\
\hline & & Yeşil Park Site & 4,5 & $-1,3$ & \\
\hline & \multirow{2}{*}{ High School } & Afet Evleri & 8,2 & $-0,5$ & \\
\hline & & Yeşil Park Site & 9,7 & 0,5 & \\
\hline & \multirow{2}{*}{ University } & Afet Evleri & 0,0 & $-7,4$ & \\
\hline & & Yeşil Park Site & 29,1 & 7,4 & \\
\hline & \multirow{2}{*}{ Postgraduate } & Afet Evleri & 0,0 & $-3,1$ & \\
\hline & & Yeşil Park Site & 6,7 & 3,1 & \\
\hline \multirow{4}{*}{ 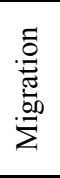 } & \multirow{2}{*}{ Came with migration } & Afet Evleri & 47,8 & 6,6 & \multirow{4}{*}{$\begin{array}{l}\text { This is because users from Afet Evleri came to } \\
\text { Trabzon with migration, and users from Yeşil } \\
\text { Park Site have been living in Trabzon for a few } \\
\text { generations. }\end{array}$} \\
\hline & & Yeşil Park Site & 21,6 & $-6,6$ & \\
\hline & \multirow{2}{*}{$\begin{array}{r}\text { In Trabzon for a few } \\
\text { generations }\end{array}$} & Afet Evleri & 2,2 & $-6,6$ & \\
\hline & & Yeşil Park Site & 28,6 & 6,6 & \\
\hline
\end{tabular}

\section{Findings Related to globalization}

Determining users' relationship with both communication tools and technology, also their social habits is important in terms of finding out how and how much they are affected from globalization. Therefore, within the scope of the study, questions were asked to users towards determining their frequency of going to cinema, reading book, going to concert or theater, watching TV, traveling, Internet usage, reading newspaper and periodicals.

In assessment made with respect to globalization, it is observed that users from Afet Evleri seldom or never carry out such activities, but Yeşil Park Site users carry out these activities regularly (Table 2 and 3). It was determined that TV viewing habits in both groups did not vary significantly, and this fact was due to lack of different options among TV shows, and it was considered that program type 
that a user watched might affect whether he/she would be affected from global markets. In interviews, it was observed that programs watched by both groups were different.

Table 2. Analysis of sample groups in terms of social organizations (Aras, 2015)

\begin{tabular}{|c|c|c|c|c|c|}
\hline \multicolumn{2}{|c|}{$\begin{array}{c}\text { Social organizations } \\
\text { affecting globalization }\end{array}$} & Sample group & $\%{ }^{*}$ & $\begin{array}{l}\text { Adj. } \\
\text { Res. }\end{array}$ & Reason for difference; \\
\hline \multirow{6}{*}{ 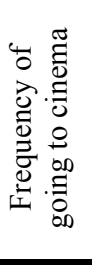 } & \multirow{2}{*}{ Regular } & Afet Evleri & 6,0 & $-9,0$ & \multirow{6}{*}{$\begin{array}{l}\text { Disaster Area Complex users rarely or never go to } \\
\text { cinema, } \\
\text { Users from Yeşil Park Complex regularly go to } \\
\text { cinema }\end{array}$} \\
\hline & & Yeşil Park Site & 44,8 & 9,0 & \\
\hline & \multirow{2}{*}{ Rarely } & Afet Evleri & 9,0 & 3,6 & \\
\hline & & Yeşil Park Site & 0,0 & $-3,6$ & \\
\hline & \multirow{2}{*}{ Never } & Afet Evleri & 35,1 & 7,0 & \\
\hline & & Yeşil Park Site & 5,2 & $-7,0$ & \\
\hline \multirow{6}{*}{ 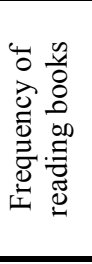 } & \multirow{2}{*}{ Regularly } & Afet Evleri & 16,4 & $-5,6$ & \multirow{6}{*}{$\begin{array}{l}\text {-Users from Disaster Area Complex rarely or } \\
\text { never read book } \\
\text { Users from Yeşil Park Complex regularly read } \\
\text { book }\end{array}$} \\
\hline & & Yeşil Park Site & 40,3 & 5,6 & \\
\hline & \multirow{2}{*}{ Rarely } & Afet Evleri & 6,7 & 3,1 & \\
\hline & & Yeşil Park Site & 0,0 & $-3,1$ & \\
\hline & \multirow{2}{*}{ Never } & Afet Evleri & 26,9 & 4,1 & \\
\hline & & Yeşil Park Site & 9,7 & $-4,1$ & \\
\hline \multirow{6}{*}{ 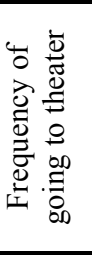 } & \multirow{2}{*}{ Regularly } & Afet Evleri & 2,2 & $-6,3$ & \multirow{6}{*}{$\begin{array}{l}\text {-Users from Disaster Area Complex do not go to } \\
\text { theater, } \\
\text { Users from Yeşil Park Complex regularly go to } \\
\text { theaters }\end{array}$} \\
\hline & & Yeşil Park Site & 26,9 & 6,3 & \\
\hline & \multirow{2}{*}{ Rarely } & Afet Evleri & 3,7 & 0,0 & \\
\hline & & Yeşil Park Site & 3,7 & 0,0 & \\
\hline & \multirow{2}{*}{ Never } & Afet Evleri & 44,0 & 5,9 & \\
\hline & & Yeşil Park Site & 19,4 & $-5,9$ & \\
\hline \multirow{6}{*}{ 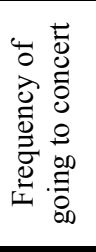 } & \multirow{2}{*}{ Regularly } & Afet Evleri & 3,7 & $-6,4$ & \multirow{6}{*}{$\begin{array}{l}\text { Users from Disaster Area Complex do not go } \\
\text { concert } \\
\text { Users from Yeşil Park Complex regularly go to } \\
\text { concerts }\end{array}$} \\
\hline & & Yeşil Park Site & 29,9 & 6,4 & \\
\hline & \multirow{2}{*}{ Rarely } & Afet Evleri & 6,7 & 0,3 & \\
\hline & & Yeşil Park Site & 6,0 & $-0,3$ & \\
\hline & \multirow{2}{*}{ Never } & Afet Evleri & 39,6 & 5,9 & \\
\hline & & Yeşil Park Site & 14,2 & $-5,9$ & \\
\hline \multirow{6}{*}{ 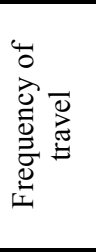 } & \multirow{2}{*}{ Regularly } & Afet Evleri & 8,2 & $-9,4$ & \multirow{6}{*}{$\begin{array}{l}\text { - Users from Disaster Area Complex rarely or } \\
\text { never travel, } \\
\text { - Users from Yeşil Park Complex regularly travel }\end{array}$} \\
\hline & & Yeşil Park Site & 48,5 & 9,4 & \\
\hline & \multirow{2}{*}{ Rarely } & Afet Evleri & 12,7 & 4,4 & \\
\hline & & Yeşil Park Site & 0,0 & $-4,4$ & \\
\hline & \multirow{2}{*}{ Never } & Afet Evleri & 29,1 & 6,9 & \\
\hline & & Yeşil Park Site & 1,5 & $-6,9$ & \\
\hline
\end{tabular}

Table 3. Analysis of sample groups in terms of media factors in globalization (Aras, 2015)

\begin{tabular}{|c|c|c|c|c|c|}
\hline \multicolumn{2}{|c|}{$\begin{array}{c}\text { Media factors affecting } \\
\text { globalization }\end{array}$} & \multirow{3}{*}{$\begin{array}{r}\text { Sample group } \\
\text { Afet Evleri } \\
\text { Yeşil Park Site }\end{array}$} & \multirow{2}{*}{$\frac{\%^{*}}{48,5}$} & \multirow{2}{*}{$\begin{array}{l}\text { Adj. } \\
\text { Res. } \\
0,0\end{array}$} & Reason for difference; \\
\hline \multirow{6}{*}{ 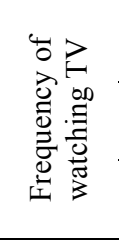 } & \multirow{2}{*}{ Regularly } & & & & \multirow{6}{*}{ No differences were found } \\
\hline & & & 48,5 & 0,0 & \\
\hline & \multirow{2}{*}{ Rarely } & Afet Evleri & 1,5 & 1,4 & \\
\hline & & Yeşil Park Site & 0,0 & $-1,4$ & \\
\hline & \multirow{2}{*}{ Never } & Afet Evleri & 0,0 & $-1,4$ & \\
\hline & & Yeşil Park Site & 1,5 & 1,4 & \\
\hline \multirow{6}{*}{ 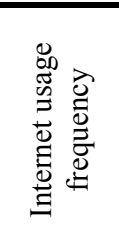 } & \multirow{2}{*}{ Regularly } & Afet Evleri & 14,2 & $-6,8$ & \multirow{6}{*}{$\begin{array}{l}\text { Users from Disaster Area Complex never use } \\
\text { Internet, } \\
\text { Users from Yeşil Park Complex regularly use } \\
\text { Internet }\end{array}$} \\
\hline & & Yeşil Park Site & 43,3 & 6,8 & \\
\hline & \multirow{2}{*}{ Rarely } & Afet Evleri & 0,0 & $-1,0$ & \\
\hline & & Yeşil Park Site & 0,7 & 1,0 & \\
\hline & \multirow{2}{*}{ Never } & Afet Evleri & 35,8 & 7,0 & \\
\hline & & Yeşil Park Site & 6,0 & $-7,0$ & \\
\hline \multirow{2}{*}{ 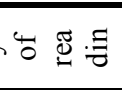 } & \multirow{2}{*}{ Regularly } & Afet Evleri & 17,9 & $-6,0$ & \multirow{2}{*}{$\begin{array}{l}\text { Users from Disaster Area Complex rarely or } \\
\text { never read newspaper }\end{array}$} \\
\hline & & Yeşil Park Site & 43,3 & 6,0 & \\
\hline
\end{tabular}


The Turkish Online Journal of Design, Art and Communication - TOJDAC

ISSN: 2146-5193, July 2018 Volume 8 Issue 3, p. 447-456

\begin{tabular}{|c|c|c|c|c|c|}
\hline & \multirow{2}{*}{ Rarely } & Afet Evleri & 4,5 & 2,5 & \multirow{4}{*}{$\begin{array}{l}\text { Users from Yeşil Park Complex regularly read } \\
\text { newspaper }\end{array}$} \\
\hline & & Yeşil Park Site & 0,0 & $-2,5$ & \\
\hline & \multirow{2}{*}{ Never } & Afet Evleri & 27,6 & 5,1 & \\
\hline & & Yeşil Park Site & 6,7 & $-5,1$ & \\
\hline \multicolumn{6}{|c|}{ Continued from Table 3} \\
\hline \multicolumn{2}{|c|}{$\begin{array}{l}\text { Media factors affecting } \\
\text { globalization }\end{array}$} & Sample group & $\%{ }^{*}$ & $\begin{array}{l}\text { Adj. } \\
\text { Res. }\end{array}$ & Reason for difference; \\
\hline \multirow{6}{*}{ 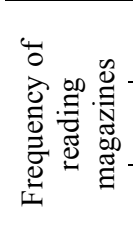 } & Reoularly & Afet Evleri & 1,5 & $-8,5$ & \multirow{6}{*}{$\begin{array}{l}\text {-Users from Disaster Area Complex never read } \\
\text { magazines, } \\
\text { Users from Yeşil Park Complex regularly read }\end{array}$} \\
\hline & Keguiarly & Yeşil Park Site & $\mathbf{3 7 , 3}$ & 8,5 & \\
\hline & Rarely & Afet Evleri & 0,7 & $-0,6$ & \\
\hline & & Yeşil Park Site & 1,5 & 0,6 & \\
\hline & \multirow{2}{*}{ Never } & Afet Evleri & 47,8 & 8,6 & \\
\hline & & Yeşil Park Site & 11,2 & $-8,6$ & \\
\hline
\end{tabular}

Besides, sample groups were examined in terms of following fashion. Because it is thought that fashion is also an effective concept in color preferences and it can be associated with globalization. Analysing sample groups' attitudes towards fashion; it can be seen that Disaster Area Complex users fed from local data and Yeşil Park Complex users fed from global data exhibit different attitudes. The reason for the difference between both social structures was determined as the fact that users from Afet Evleri did not follow fashion and users from Yeşil Park Site followed fashion (Table 4). Considering furniture preference criteria, effects of following fashion or else will be examined within the scope of the study.

Table 4. Analysis of sample groups in terms of attitude towards fashion (Aras, 2015)

\begin{tabular}{|c|c|c|c|c|}
\hline \multirow{3}{*}{ Users' attitudess towards fashion } & \multicolumn{4}{|c|}{ Sample group } \\
\hline & \multicolumn{2}{|c|}{ Afet Evleri } & \multicolumn{2}{|c|}{ Yeşil Park Site } \\
\hline & $\%$ & Adj. Res. & $\%$ & Adj. Res. \\
\hline Following & 7,5 & $-5,2$ & 7,5 & $-5,2$ \\
\hline Not following & 42,5 & 5,2 & 42,5 & 5,2 \\
\hline $\mathrm{X}^{2}$ & \multicolumn{4}{|c|}{27,057} \\
\hline $\mathrm{df}$ & \multicolumn{4}{|c|}{1} \\
\hline+2 & \multicolumn{4}{|c|}{0,000} \\
\hline
\end{tabular}

\section{Findings Related to Furniture Color Preferences}

In the determination study applied, colors of wooden furniture and colors of furniture upholsteries were examined in housing units. Within the scope of this study, colors were assessed in terms of their types, and elements such value and saturation wwere not taken into consideration. In addition, ceiling, wall and floor colors and light and material properties in spaces were not taken into consideration. That is because in the study, it is thought that users in general can easily change furniture colors by request, and the objective was to determine which colors users affected from globalization and those not affected from globalization chose in their furniture selections. It is not possible to come across with the same material and light characteristics, and same ceiling, wall and flooring colors in different buildings selected for survey. That is because selected spaces are not predetermined experimental environments, but these are actively used housing units where participants live. Therefore, the abovementioned data were not included into assessment.

In questionnaire form created in the study, a scale was established with white color used in modern architecture in addition to red, blue, yellow, green, brown and black colors used in traditional Turkish housing couches. Since it was determined that brown and white colors were used for wooden furniture, a grouping consisting of these colors was applied. Accordingly, colors used in furniture upholstery and wooden furniture were determined for each housing unit. 
Then, colors used for furniture in living spaces of housing units from the sampling groups were determined, color preferences belonging to user group in both social structure groups were compared using SPSS software and examined statistically. Since $p$ value (significance value) is taken at $95 \%$ reliability in studies conducted in the field of social sciences, variables with significant relationship of $\mathrm{p}<0.05$ were examined within the scope of the study. If $\mathrm{p}<0.05$, it means that there is statistically significant difference among both groups; if $\mathrm{p}>0.05$, it means that there are no significant differences among both groups.

The sample groups were evaluated in terms of furniture upholstery colors they used. Difference between both social structures in terms of furniture upholstery colors in living spaces stems from that the use of brown (23.1\%) and red (6.7\%) in houses from Afet Evleri, and white (19\%) in houses from Yeşil Park Site (Table 5).

Table 5. Analysis of colors used in furniture upholstery in living spaces of housing units belonging to different social structures (Aras, 2017)

\begin{tabular}{|c|c|c|c|c|}
\hline \multirow{3}{*}{ Furniture upholstery colors in living spaces } & \multicolumn{4}{|c|}{ Sample group } \\
\hline & \multicolumn{2}{|c|}{ Afet Evleri } & \multicolumn{2}{|c|}{ Yessil Park Site } \\
\hline & $\%$ & Adj. Res. & $\%$ & Adj. Res. \\
\hline White & 0,0 & $-4,7$ & 0,0 & $-4,7$ \\
\hline Black & 0,7 & 1,0 & 0,7 & 1,0 \\
\hline Brown & 23,1 & 2,1 & 23,1 & 2,1 \\
\hline Green & 2,2 & 1,0 & 2,2 & 1,0 \\
\hline Blue & 0,7 & 0,0 & 0,7 & 0,0 \\
\hline Red & 6,7 & 3,1 & 6,7 & 3,1 \\
\hline Mixed & 14,2 & $-1,1$ & 14,2 & $-1,1$ \\
\hline Other & 2,2 & 0,5 & 2,2 & 0,5 \\
\hline LR & \multicolumn{4}{|c|}{45,179} \\
\hline $\mathrm{df}$ & \multicolumn{4}{|c|}{7} \\
\hline 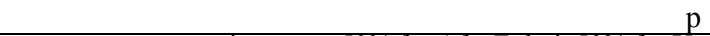 & \multicolumn{4}{|c|}{0,000} \\
\hline
\end{tabular}

Sample groups were evaluated in terms of wooden furniture colors they used. Difference between both social structures in terms of wooden furniture colors in living spaces stems from the use of brown $(50 \%)$ in houses from Afet Evleri and use of brown and white combination (27.6\%) in houses from Yeşil Park Site (Table 6).

Table 6. Analysis of color used in wooden furniture in living spaces of housing units belonging to different social structures (Aras, 2017)

\begin{tabular}{|c|c|c|c|c|}
\hline \multirow{3}{*}{ Wooden furniture colors in living spaces } & \multicolumn{4}{|c|}{ Sample group } \\
\hline & \multicolumn{2}{|c|}{ Afet Evleri } & \multicolumn{2}{|c|}{ Yeşil Park Site } \\
\hline & $\%$ & Adj. Res. & $\%$ & Adj. Res. \\
\hline Brown & $\mathbf{5 0 , 0}$ & 7,3 & $\mathbf{5 0 , 0}$ & 7,3 \\
\hline White & 0,0 & $-1,0$ & 0,0 & $-1,0$ \\
\hline Brown and white & 0,0 & $-7,1$ & 0,0 & $-7,1$ \\
\hline LR & \multicolumn{4}{|c|}{68,141} \\
\hline $\mathrm{df}$ & \multicolumn{4}{|c|}{8} \\
\hline $\mathrm{p}$ & \multicolumn{4}{|c|}{$0, \mathrm{c}$} \\
\hline
\end{tabular}

Consequently, statistical significant difference was found among colors of both furniture upholstery and wooden furniture in living spaces of housing units from both social structures (Figure 2). 


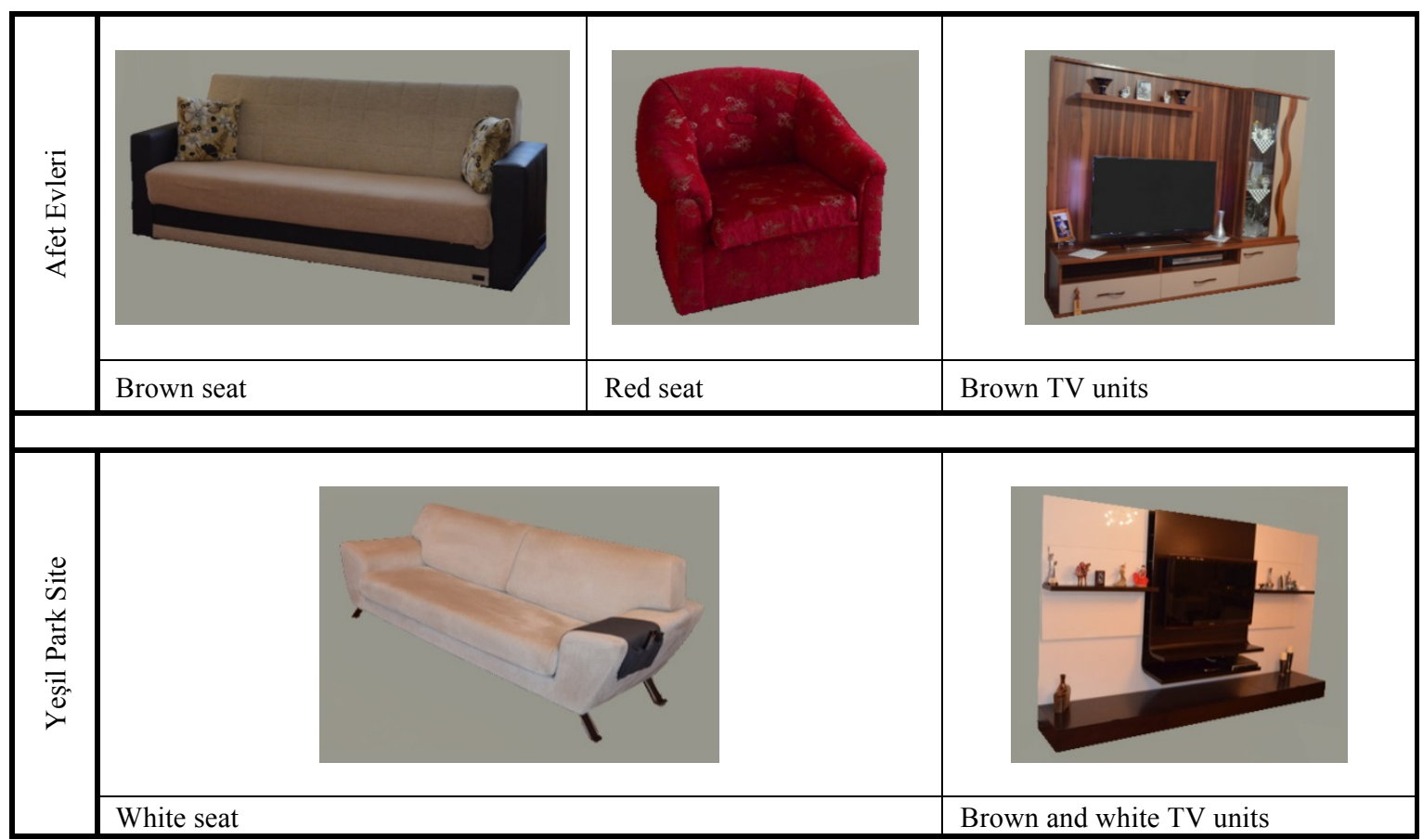

Figure 2. Examples of space and furniture used in different social structures

\section{CONCLUSION}

Globalization affects many factors ranging from community's lifestyle to tastes, from preferences to behavior patterns. In addition, it has also an important place in shaping the environment in which individuals live especially including houses. Living spaces, on the other hand, emerge as places for which users assign symbolic meanings and where guests can obtain first impressions about housing units. These spaces are places where an individual gives some messages to others. Among these symbolic expressions used by individuals knowingly or unknowingly, color is also considered effective in conveying such symbolic meanings. For this purpose, this study has examined whether there are differences in colors of furniture in living spaces of housing units belonging to users from different social structures.

As a result of statistical analyses conducted, it was determined that there were differences in furniture color preferences among users from Yeşil Park Site who were found to be affected more from globalization and users from Afet Evleri who were found to be less affected from globalization. It is observed that users from Afet Evleri who feed with local data use brown and red colors that are generally used in traditional Turkish housing units, and users from Yeşil Park Site who feed with global data use white and brown-white combinations that are symbols of modernism and purity, used in modern buildings, and that were popular during the time of study. In accordance with data obtained from the study, it is concluded that there are differences among furniture colors in living spaces of housing units preferred by users who are affected from globalization and by those who are not affected from globalization, and consequently, the objective of the study has been reached. It can be said that furniture colors vary in Turkish society together with evolving communication facilities.

\section{REFERENCES}

Aylin, Aras, (2015). Interaction of Culture Components and Cultural Groups in Spatial Organizations Choosing Furniture: House Living Rooms (in Turkish) (PhD Thesis). Karadeniz Technical University Institute of Natural \& Applied Sciences, Trabzon.

Aylin, Aras, (2017). Colours Preferences in Housing Furniture by Two Different Culture Groups, International Journal of Architectural Engineering Technology, 4, 54-58.

Banu, Manav, (2011). "Hacimde Bir Tasarım Parametresi Olarak Renk", Sanat ve Tasarım Dergisi, 1 (8), 93-102. Retrieved from http://dergipark.gov.tr/sanatvetasarim/issue/20659/220398, 25 Nisan 2018 
Banu, Manav, (2015). "Renk-Anlam-Mekan Ilişkisi”, The Turkish Online Journal of Design, Art and Communication - TOJDAC July 2015 Volume 5 Issue 3, 22-27, Retrieved from http://www.tojdac.org/tojdac/VOLUME5-ISSUE3 files/tojdac v05i303.pdf, 24 Nisan 2018

Chaney, David, (1999). Lifestyles (in Turkish) (I Kutluk, Trans.), Ankara: Dost Publishing.

Doğan, Hasol, (1975). Ansiklopedik Mimarlı Sözlüğ̈̈, İstanbul: Y.E.M., s: 379.

Funda, Kurak Açıcı, (2015). İ̧ Mekânda Sınır Öğeleri, Ankara: Akademisyen Kitabevi.

Handan, Özsırkıntı Kasap, (2009). 20. Yüzyıl Mimarisinde Form ve Renk Kavramlarının Mekâna Etkisinin Mimari Akımlar Çerçevesinde Analizi, Mimar Sinan Güzel Sanatlar Üniversitesi Fen Bilimleri Enstitüsü Sanatta Yeterlik Tezi, İstanbul.

Hofstede, Geert, (1991). Cultures and Organizations: Software of The Mind, London: Harper Collins Publication.

Illhan, Altan, (1993). "Mimarlikta Mekân Kavramı" Psikoloji Çalı̧̧maları Dergisi, 19: 75-88.

James Joseph, Sheppard, (1968). Human Color Perception: A Critical Study of The Experimental Foundation, New York: American Elsevier Publishing Company, S. 9

Önder, Kü̧̈ükerman, (1991). Turkish House in Search of Spatial Identity (in Turkish), Istanbul: The Turkish Turing Automobile Club Publishing.

Sencer, Ayata ve Ayşe, Güneş Ayata, (1996). Konut, Komşuluk ve Kent Kültürü, T. C. Başbakanlık Toplu Konut İdaresi Başkanlı̆̆ı Konut Araştırmaları Dizisi 10, Ankara.

Tülay, Özdemir, (2005). "The Criteria That Influence The Choice of Color in Design" (in Turkish), Journal of Çukurova University Institute of Social Sciences; 14, 2, 391-402. 